\title{
Inositol 1,4,5-Triphosphate-Evoked Responses in Midbrain Dopamine Neurons
}

\author{
Hitoshi Morikawa, ${ }^{1}$ Farzin Imani, ${ }^{2}$ Kamran Khodakhah, ${ }^{2}$ and John T. Williams ${ }^{1}$ \\ 1 Vollum Institute, Oregon Health Sciences University, Portland, Oregon 97201, and 2Department of Physiology and \\ Biophysics, University of Colorado Health Sciences Center, Denver, Colorado 80262
}

Synaptically released glutamate evokes slow IPSPs mediated by metabotropic glutamate receptors (mGluRs) in midbrain dopamine neurons. These mGluR IPSPs are caused by release of $\mathrm{Ca}^{2+}$ from intracellular stores and subsequent activation of small-conductance $\mathrm{Ca}^{2+}$-activated $\mathrm{K}^{+}$channels (SK channels). To further investigate the intracellular mechanisms involved, the effect of photolyzing intracellular caged inositol 1,4,5-triphosphate $\left(\operatorname{InsP}_{3}\right)$ on membrane conductance and intracellular $\mathrm{Ca}^{2+}$ concentration $\left(\left[\mathrm{Ca}^{2+}\right]_{\mathrm{i}}\right)$ was examined in rat midbrain slices. Photolytic release of $\operatorname{lns}_{3}$ elicited a transient outward current and a sharp rise in $\left[\mathrm{Ca}^{2+}\right]_{\mathrm{i}}$ that lasted for $\sim 5$ sec. Apamin, a blocker of SK channels, abolished the Ins $\mathrm{P}_{3}$ induced outward current without affecting the rise in $\left[\mathrm{Ca}^{2+}\right]_{\text {i }}$. Depleting intracellular $\mathrm{Ca}^{2+}$ stores with cyclopiazonic acid completely blocked both the outward current and the $\mathrm{Ca}^{2+}$ transient elicited by $\operatorname{Ins} \mathrm{P}_{3}$. Ins $\mathrm{P}_{3}$-evoked $\mathrm{Ca}^{2+}$ mobilization was not affected by blockade of ryanodine receptors with ruthenium red, whereas depleting ryanodine-sensitive $\mathrm{Ca}^{2+}$ stores with ryanodine almost eliminated InsP $\mathrm{P}_{3}$-induced $\mathrm{Ca}^{2+}$ release. Increasing the size of intracellular $\mathrm{Ca}^{2+}$ stores by means of prolonged depolarization added a late component to the outward current and a slow component to the rising phase of $\left[\mathrm{Ca}^{2+}\right]_{i}$. These effects of depolarization were blocked by ruthenium red. These results show that $\operatorname{InsP}_{3}$ activates SK channels by releasing $\mathrm{Ca}^{2+}$ from InsP $_{3}$-sensitive stores that also contain ryanodine receptors. Increasing intracellular $\mathrm{Ca}^{2+}$ stores boosts InsP $\mathrm{P}_{3}$-evoked responses by invoking $\mathrm{Ca}^{2+}$ induced $\mathrm{Ca}^{2+}$ release through ryanodine receptors. This intracellular signaling pathway may play a significant role in regulating the excitability of midbrain dopamine neurons.

Key words: intracellular $\mathrm{Ca}^{2+}$; inositol 1,4,5-triphosphate; inositol 1,4,5-triphosphate receptors; ryanodine receptors; SK channels; midbrain dopamine neurons; flash photolysis
Intracellular $\mathrm{Ca}^{2+}$ plays a pivotal role in controlling the excitability of neurons by activating various $\mathrm{Ca}^{2+}$-sensitive ion channels on the plasma membrane (Vergara et al., 1998). One major pathway to elevate intracellular $\mathrm{Ca}^{2+}$ concentration $\left(\left[\mathrm{Ca}^{2+}\right]_{\mathrm{i}}\right)$ is mobilization of $\mathrm{Ca}^{2+}$ from intracellular stores. This is achieved by activating inositol 1,4,5-triphosphate $\left(\mathrm{InsP}_{3}\right)$ receptors or ryanodine receptors located on the membranes of these stores. Firing of presynaptic fibers is known to evoke a rise in $\left[\mathrm{Ca}^{2+}\right]_{\mathrm{i}}$ in postsynaptic neurons, mainly via $\mathrm{Ca}^{2+}$ influx (Denk et al., 1996). Recent evidence has demonstrated that synaptically released glutamate, acting at metabotropic glutamate receptors (mGluRs), results in the generation of $\mathrm{InsP}_{3}$ and subsequent mobilization of $\mathrm{Ca}^{2+}$ in cerebellar Purkinje neurons (Finch and Augustine, 1998; Takechi et al., 1998) and hippocampal pyramidal neurons (Nakamura et al., 1999).

Dopaminergic neurons in the ventral midbrain (ventral tegmental area and substantia nigra pars compacta) are involved in the perception of reward, motivational behavior, and the reinforcing actions of addictive drugs. In addition, impaired functioning of dopamine neurons is associated with the etiology of human disorders such as Parkinson's disease and schizophrenia (for review, see Schultz, 1998). It has recently been shown that glutamate released from presynaptic terminals elicits slow IPSPs mediated by activation of mGluRs in midbrain dopamine neurons (Fiorillo and Williams, 1998). This mGluR-mediated hyperpolar-

\footnotetext{
Received June 28, 2000; revised Aug. 1, 2000; accepted Aug. 1, 2000.

This work was supported by National Institutes of Health Grant DA08163, a National Ataxia Foundation grant, and a Uehara Memorial Foundation fellowship. We thank Drs. James M. Brundege, Carlos Paladini, and Laura S. Stone for helpful comments on this manuscript.

Correspondence should be addressed to John T. Williams, Vollum Institute, Oregon Health Sciences University, 3181 SW Sam Jackson Park Road, Portland, OR 97201. E-mail: williamj@ohsu.edu.

Copyright (C) 2000 Society for Neuroscience $\quad 0270-6474 / 00 / 200001-\bullet \$ 15.00 / 0$
}

ization results from mobilization of $\mathrm{Ca}^{2+}$ from intracellular stores, probably through production of $\mathrm{InsP}_{3}$, and subsequent activation of small-conductance $\mathrm{Ca}^{2+}$-activated $\mathrm{K}^{+}$channels (SK channels). Furthermore, spontaneous release of $\mathrm{Ca}^{2+}$ from internal stores has been implicated in the generation of spontaneous hyperpolarizations observed in dopamine neurons from neonatal rats (Seutin et al., 2000). The involvement of ryanodinesensitive $\mathrm{Ca}^{2+}$ stores has been suggested in both cases on the basis of sensitivity to caffeine and ryanodine.

In the present study, the intracellular signaling pathway ensuing from the generation of $\mathrm{InsP}_{3}$ was investigated in midbrain dopamine neurons using flash photolysis of caged $\operatorname{InsP}_{3}$ loaded into the cell (Walker et al., 1989). The results demonstrate that $\mathrm{InsP}_{3}$ elicits activation of SK channels through mobilization of $\mathrm{Ca}^{2+}$ from intracellular stores and that these $\operatorname{InsP}_{3}$-sensitive stores are invariably equipped with ryanodine receptors. In addition, $\mathrm{Ca}^{2+}$-induced $\mathrm{Ca}^{2+}$ release (CICR) through ryanodine receptors was found to boost $\mathrm{InsP}_{3}$-evoked release of $\mathrm{Ca}^{2+}$ when internal $\mathrm{Ca}^{2+}$ stores were filled by depolarization-induced $\mathrm{Ca}^{2+}$ influx.

This article is published in The Journal of Neuroscience, Rapid Communications Section, which publishes brief, peerreviewed papers online, not in print. Rapid Communications are posted online approximately one month earlier than they would appear if printed. They are listed in the Table of Contents of the next open issue of JNeurosci. Cite this article as: JNeurosci, 2000, 20:RC103 (1-5). The publication date is the date of posting online at www.jneurosci.org.

http://www.jneurosci.org/cgi/content/full/4615 


\section{MATERIALS AND METHODS}

Whole-cell recordings were made from dopamine neurons in horizontal midbrain slices $(250 \mu \mathrm{m})$ from Wistar rats $(10-21 \mathrm{~d})$. Preparation of slices has been described previously (Cameron and Williams, 1994). Slices were placed in a recording chamber and superfused with warmed $\left(35^{\circ} \mathrm{C}\right)$ physiological saline containing (in $\mathrm{mM}$ ): $125 \mathrm{NaCl}, 2.5 \mathrm{KCl}, 1$ $\mathrm{MgCl}_{2}, 26 \mathrm{NaHCO}_{3}, 1.25 \mathrm{NaH}_{2} \mathrm{PO}_{4}, 11$ glucose, $2.4 \mathrm{CaCl}_{2}$, bubbled with $95 \% \mathrm{O}_{2} / 5 \% \mathrm{CO}_{2} ; \mathrm{pH} 7.4,295 \mathrm{mOsm} / \mathrm{kg}$. Cells were visualized using an upright microscope with infrared optics, and recordings were made with patch pipettes containing (in $\mathrm{mM}$ ): $145 \mathrm{KMeSO}_{4}, 8 \mathrm{KCl}, 10 \mathrm{HEPES}, 2$ MgATP, and 0.2 GTP; $\mathrm{pH} 7.2,285 \mathrm{mOsm} / \mathrm{kg}$. The pipette solution also contained Fura-6F (500 $\mu \mathrm{M}$; Molecular Probes, Eugene, OR) and caged InsP $\mathrm{P}_{3}[100 \mu \mathrm{M}$; made in house; Womack et al. (2000)]. Ruthenium red (20 $\mu \mathrm{M}$; Calbiochem, San Diego, CA) or ryanodine (10 $\mu \mathrm{M}$; Sigma, St. Louis, MO) was added to the pipette solution when indicated. The membrane potential was clamped at $-60 \mathrm{mV}$ unless stated otherwise. Recordings were started at least 15 min after whole-cell access was gained to ensure equilibrium of the pipette solution with the cytosol. Dopamine cells were identified by the presence of a large $I_{\mathrm{H}}$ current $(>200 \mathrm{pA}$ at $-120 \mathrm{mV})$ (Johnson and North, 1992).

In experiments in which mGluR-mediated IPSCs were measured, EGTA $(100 \mu \mathrm{M})$ was added to the pipette solution instead of Fura-6F and caged InsP $\mathrm{P}_{3}$. The superfusion medium contained 2,3-dihydroxy-6-nitro7-sulfamoylbenzo[f]-quinoxaline $(5 \mu \mathrm{M})$, picrotoxin $(100 \mu \mathrm{M})$, and CGP35348 $(100 \mu \mathrm{M})$ to block AMPA-, GABA $\mathrm{A}^{-}$, and GABA ${ }_{\mathrm{B}^{-m} \text {-mediated }}$ synaptic currents, and slices were pretreated with MK-801 $(50 \mu \mathrm{M})$ to block the NMDA-mediated synaptic current. A train of 10 stimuli (500 $\mu \mathrm{sec}$ at $70 \mathrm{~Hz}$ ) was delivered every $60 \mathrm{sec}$, using a bipolar tungsten stimulating electrode placed close $(30-100 \mu \mathrm{m})$ to the soma. The stimulus intensity was adjusted to obtain a maximal IPSC in each cell. The slow IPSC thus recorded was inhibited by the mGluR antagonist $(S)-\alpha-$ methyl-4-carboxyphenylglycine (1 mM).

Fluorescence measurements were made from an area just covering the soma, defined by a rectangular diaphragm in a conjugate image plane of the microscope. The $\mathrm{Ca}^{2+}$ indicator dye Fura- $6 \mathrm{~F}\left(K_{\mathrm{d}}=5.3 \mu \mathrm{M}\right)$, introduced into the cell via the whole-cell patch pipette, was excited at a single wavelength of $425 \pm 15 \mathrm{~nm}$, and the emitted light was collected at $510 \pm$ $15 \mathrm{~nm}$. Fura indicators, when fully saturated with $\mathrm{Ca}^{2+}$, emit negligible fluorescence when excited at $\sim 420 \mathrm{~nm}$ (Ogden et al., 1995). $\left[\mathrm{Ca}^{2+}\right]_{\mathrm{i}}$ was calculated from the formula $\left[\mathrm{Ca}^{2+}\right]=K_{\mathrm{d}}\left(F-F_{\min }\right) /\left(F_{\max }-F\right)$, where $F$ is the background-corrected fluorescence, $F_{\min }$ is fluorescence of the indicator at $0\left[\mathrm{Ca}^{2+}\right]$, and $F_{\max }$ is fluorescence of the indicator at saturating $\left[\mathrm{Ca}^{2+}\right]$, which was assumed to be zero as stated above. $F_{\min }$ was obtained in each cell by assuming that the resting fluorescence emitted by the indicator, after background correction, reflects fluorescence at $50 \mathrm{~nm}\left[\mathrm{Ca}^{2+}\right]$.

A xenon arc lamp (Carin Research, Faversham, UK) produced UV pulses of $\sim 1 \mathrm{msec}$ in duration to photolyze a known fraction of caged $\mathrm{InsP}_{3}$ loaded into the cytosol. The interval between two successive pulses was $>4$ min to allow reequilibration of caged $\mathrm{InsP}_{3}$ with the cytosol. The extent of photolysis was calibrated using a fluorescent $\mathrm{pH}$ indicator, taking advantage of the stoichiometric release of a proton with ATP during photolysis of caged MgATP, which has the same photolytic efficiency as caged $\mathrm{InsP}_{3}$ (Walker et al., 1988).

Data are expressed as means \pm SEM. Statistical significance was determined with Student's $t$ test (unpaired or paired) or ANOVA. The difference was considered significant if $p<0.05$.

\section{RESULTS}

\section{Intracellular Ins $\mathrm{P}_{3}$ induces $\mathrm{SK}$ channel activation in dopamine neurons}

Whole-cell recordings (holding potential, $-60 \mathrm{mV}$ ) were made from dopamine neurons dialyzed with the calcium indicator Fura-6F $(500 \mu \mathrm{M})$ and caged $\operatorname{InsP}_{3}(100 \mu \mathrm{M})$ in ventral midbrain slices. Pulses of UV light $(1 \mathrm{msec})$ were applied to rapidly release $\left(\sim 3 \mathrm{msec}\right.$ ) (Walker et al., 1989) a known concentration of $\mathrm{InsP}_{3}$, and the resulting changes in membrane current and fluorescence were measured. Photolytic release of $\operatorname{InsP}_{3}(30 \mu \mathrm{M})$ in the cytosol elicited a transient outward current and a rapid rise in $\left[\mathrm{Ca}^{2+}\right]_{\mathrm{i}}$, which decayed over a period of $\sim 5 \sec ($ Fig. $1 A$ ). The outward current invariably decayed faster than $\left[\mathrm{Ca}^{2+}\right]_{\mathrm{i}}$, which may reflect the actual subplasmalemmal $\left[\mathrm{Ca}^{2+}\right]_{\mathrm{i}}$ and also the steep $\mathrm{Ca}^{2+}$ concentration-dependence of apamin-sensitive SK channels (Köhler et al., 1996). On average, the amplitude of the peak outward current and the magnitude of the increase in $\left[\mathrm{Ca}^{2+}\right]_{i}$ produced by $\operatorname{InsP}_{3}(30 \mu \mathrm{M})$ was $104 \pm 18 \mathrm{pA}$ and $1.1 \pm 0.1 \mu \mathrm{M}$, respectively $(n=18)$. These $\mathrm{InsP}_{3}$-evoked responses were reproducible throughout the duration of recordings $(\sim 3 \mathrm{hr})$.
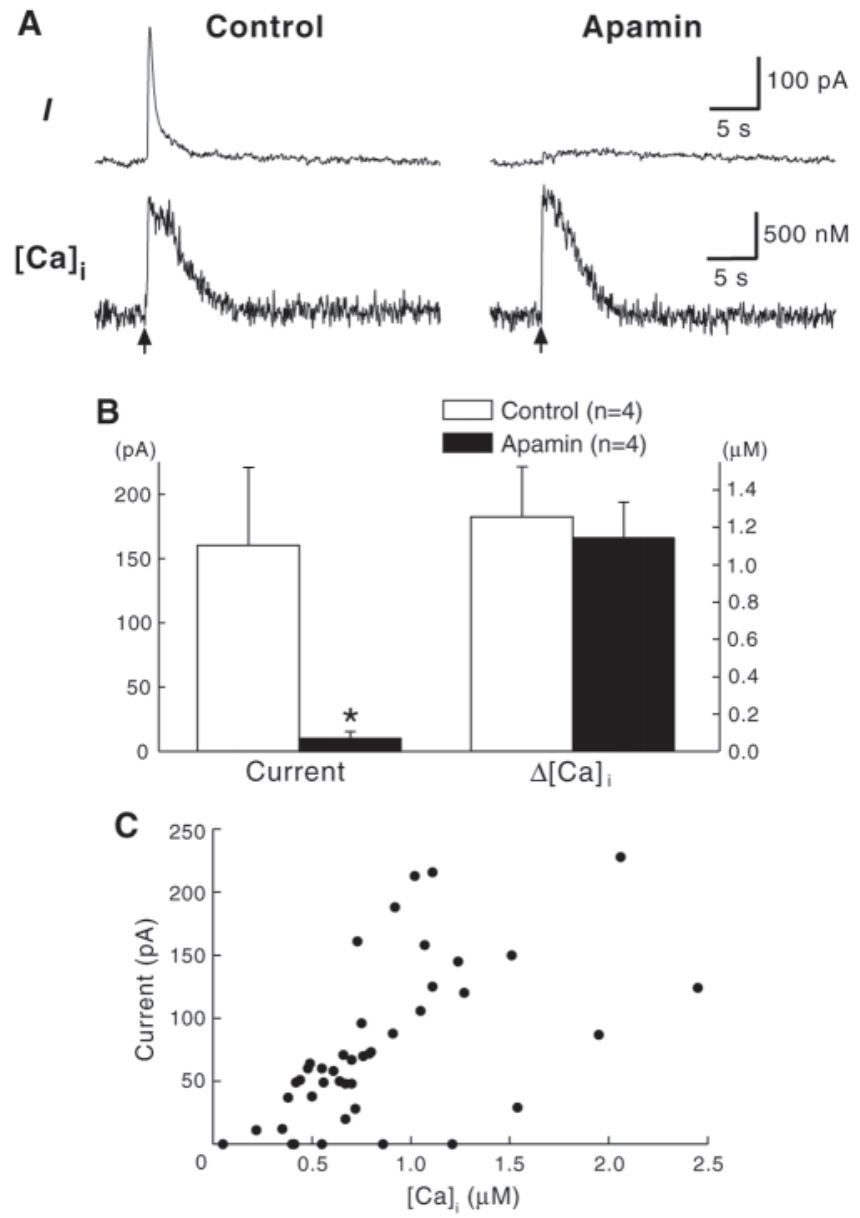

Figure 1. Photolytic release of InsP $\mathrm{P}_{3}$ induced apamin-sensitive SK channel activation in dopamine neurons. $A$, A pulse of UV light ( $1 \mathrm{msec}$ ) was applied at the time indicated by the arrow to rapidly release $\operatorname{InsP}_{3}(30 \mu \mathrm{M})$ in the cytosol. The resulting changes in membrane current (top traces) and $\left[\mathrm{Ca}^{2+}\right]_{\mathrm{i}}$ (bottom traces) are shown before (left) and after (right) bath application of apamin (100 nM). B, Pooled data from four cells tested for the effect of apamin $(100 \mathrm{~nm}) .{ }^{*} p<0.05$. $C$, Scatter plot of the amplitude of outward current versus the peak $\left[\mathrm{Ca}^{2+}\right]_{\mathrm{i}}$ evoked by photolytic release of $\operatorname{InsP}_{3}(0.75-30 \mu \mathrm{M})$. The data are from 18 cells. Up to five different concentrations of InsP $P_{3}$ were tested in each cell.

Extracellular application of apamin (100 nM), a blocker of SK channels (Köhler et al., 1996), irreversibly blocked the $\operatorname{InsP}_{3}$ induced outward current $(10 \pm 4 \%$ of control, $n=4)$ without significantly affecting the $\left[\mathrm{Ca}^{2+}\right]_{\mathrm{i}}$ elevation $(94 \pm 5 \%$ of control, $n=4$ ) (Fig. $1 A, B)$. The amplitude of the outward current produced by various concentrations of $\operatorname{InsP}_{3}(0.75-30 \mu \mathrm{M})$ correlated with the peak $\left[\mathrm{Ca}^{2+}\right]_{\mathrm{i}}(r=0.70)($ Fig. $1 C)$.

The effects of cyclopiazonic acid (CPA) on the $\mathrm{InsP}_{3}$-evoked responses were examined next. CPA depletes intracellular $\mathrm{Ca}^{2+}$ stores by blocking the endoplasmic reticulum $\mathrm{Ca}^{2+}$-ATPase (Seidler et al., 1989). The experiment in Figure $2 A$ illustrates that bath application of CPA $(10 \mu \mathrm{M})$ completely abolished both the outward current and the rise in $\left[\mathrm{Ca}^{2+}\right]_{i}$ evoked by $\operatorname{InsP}_{3}$. In five cells tested, CPA $(10 \mu \mathrm{M})$ reduced the $\mathrm{InsP}_{3}$-induced increase in $\left[\mathrm{Ca}^{2+}\right]_{\mathrm{i}}$ to $9 \pm 4 \%$ of control and completely inhibited the outward current (Fig. 2B). In contrast, CPA had no effect on the rise in $\left[\mathrm{Ca}^{2+}\right]_{i}$ caused by a depolarizing step to $0 \mathrm{mV}(1 \mathrm{sec})$, although it slowed the decay time course of $\left[\mathrm{Ca}^{2+}\right]_{\mathrm{i}}$ after depolarization (Fig. 2A).

Taken together, these results indicate that $\mathrm{InsP}_{3}$ released in the cytosol mobilizes $\mathrm{Ca}^{2+}$ from intracellular stores and activates apamin-sensitive SK channels. 
A
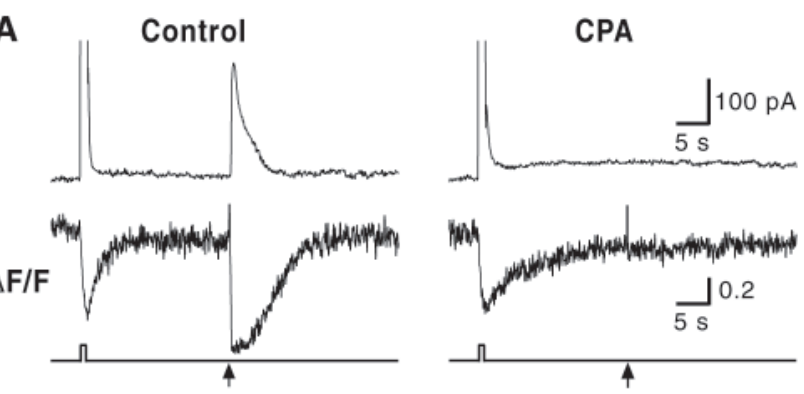

B

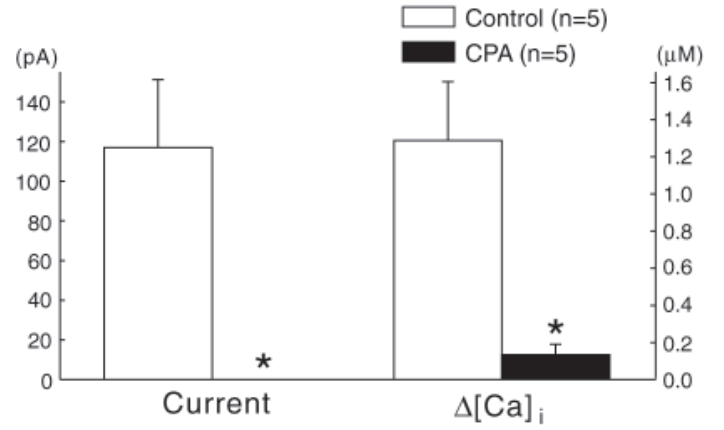

Figure 2. Depletion of intracellular $\mathrm{Ca}^{2+}$ stores abolished $\mathrm{InsP}_{3}$-evoked responses. $A$, A depolarizing step to $0 \mathrm{mV}(1 \mathrm{sec}$; voltage protocol illustrated below) followed 20 sec later by photolytic release of $\operatorname{InsP}_{3}(30$ $\mu \mathrm{M}$; arrow) was applied before (left) and after (right) perfusion of CPA $(10 \mu \mathrm{M})$. The resulting changes in membrane current (top traces) and fluorescence (bottom traces) are shown. In this cell, a high-affinity $\mathrm{Ca}^{2+}$ indicator Fura-2 $\left(200 \mu \mathrm{M} ; k_{\mathrm{d}}=140 \mathrm{nM}\right)$ was used to enhance detection of small changes in $\left[\mathrm{Ca}^{2+}\right]_{\mathrm{i}}$. The fluorescence was therefore not converted to $\left[\mathrm{Ca}^{2+}\right]_{\mathrm{i}} . B$, Pooled data from five cells tested for the effect of CPA (10 $\mu \mathrm{M}) . * p<0.05$.

\section{Ins $\mathrm{P}_{3}$ receptors and ryanodine receptors are} colocalized on the same intracellular $\mathrm{Ca}^{2+}$ stores

It has been suggested that activation of mGluRs triggers CICR through ryanodine receptors in midbrain dopamine neurons (Fiorillo and Williams, 1998). To investigate whether photolytic release of $\mathrm{InsP}_{3}$ evokes CICR, the contribution of ryanodine receptors was assessed with ruthenium red and ryanodine. Ruthenium red is a blocker of ryanodine receptors, whereas ryanodine locks ryanodine receptor channels in a subconductance open state and depletes ryanodine-sensitive $\mathrm{Ca}^{2+}$ stores (Smith et al., 1988). Ruthenium red (20 $\mu \mathrm{M}$ in the patch pipette) had no significant effect on the outward current or the rise in $\left[\mathrm{Ca}^{2+}\right]_{\mathrm{i}}$ caused by release of $\operatorname{InsP}_{3}(30 \mu \mathrm{M})$ (Fig. $\left.3 A\right)$, indicating that CICR through ryanodine receptors does not play a major role in the $\mathrm{InsP}_{3^{-}}$ induced mobilization of $\mathrm{Ca}^{2+}$. Furthermore, the amplitude of mGluR IPSCs elicited by extracellular stimuli was not significantly different between control and ruthenium red-containing internal solutions $(121 \pm 26 \mathrm{pA}, n=5$ vs $106 \pm 25 \mathrm{pA}, n=6, p>$ $0.6)$. In contrast, ryanodine (10 $\mu \mathrm{M}$ in the patch pipette) almost completely blocked $\mathrm{InsP}_{3}$-induced responses (Fig. $3 A$ ). However, after a depolarizing step $(5 \mathrm{sec})$ to $0 \mathrm{mV}$, InsP $\mathrm{P}_{3}$ elicited a clear increase in $\left[\mathrm{Ca}^{2+}\right]_{\mathrm{i}}$ and a small outward current even in the presence of ryanodine. The effect of depolarization lasted for at least $30 \mathrm{sec}(n=3)$. This observation suggests that $\mathrm{Ca}^{2+}$ entry during depolarization partially refilled the $\mathrm{InsP}_{3}$-sensitive stores that had been depleted by ryanodine. The inhibitory action of ryanodine $(10 \mu \mathrm{M})$ was fully blocked by co-addition of ruthenium red $(20 \mu \mathrm{M})$ to the internal solution (Fig. $3 A)$.

Taken together, these data strongly suggest that $\mathrm{InsP}_{3}$ elicits $\mathrm{Ca}^{2+}$ mobilization from the $\mathrm{InsP}_{3}$-sensitive stores that also express ryanodine receptors but does not trigger CICR through these ryanodine receptors.
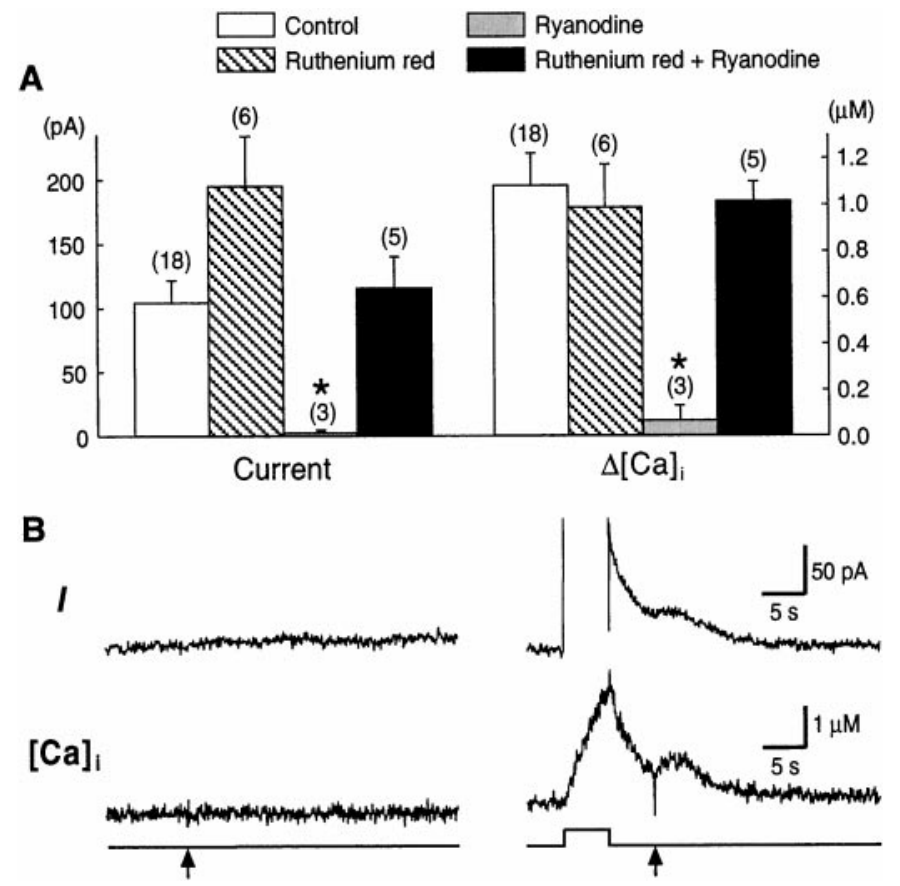

Figure 3. The effects of ruthenium red and ryanodine on $\operatorname{InsP}_{3}$-induced responses. $A$, Summary histogram showing $\mathrm{InsP}_{3}$-evoked responses in cells dialyzed with control pipette solution, ruthenium red $(20 \mu \mathrm{M})$, ryanodine $(10 \mu \mathrm{M})$, and both ruthenium red $(20 \mu \mathrm{M})$ and ryanodine $(10$ $\mu \mathrm{M})$. The number of cells tested is indicated in parentheses. ${ }^{*} p<0.05 . B$, InsP $_{3}(30 \mu \mathrm{M})$ was released at the time indicated by the arrow without (left) or with (right) a preceding depolarizing step to $0 \mathrm{mV}(5 \mathrm{sec})$ in a cell dialyzed with ryanodine $(10 \mu \mathrm{M})$. The voltage protocol is shown below. The interval between the depolarizing step and release of InsP $\mathrm{P}_{3}$ was 5 sec. Top traces and bottom traces depict membrane current and $\left[\mathrm{Ca}^{2+}\right]_{\mathrm{i}}$, respectively.

\section{Increasing $\mathrm{Ca}^{2+}$ stores invokes $\mathrm{CICR}$}

We next asked under what conditions ryanodine receptors could be activated in dopamine neurons. Repetitive firing of dopamine neurons for $20-50 \mathrm{sec}$ has been shown to induce transient facilitation of mGluR IPSPs that lasts for several minutes, an effect that may be caused by loading of intracellular $\mathrm{Ca}^{2+}$ stores (Fiorillo and Williams, 1998). Thus, filling internal $\mathrm{Ca}^{2+}$ stores by prolonged depolarization may invoke a component of the $\mathrm{InsP}_{3}-$ evoked $\mathrm{Ca}^{2+}$ release that is attributable to CICR. A prolonged depolarization $(20 \mathrm{sec})$ was applied $1 \mathrm{~min}$ before photolytic release of InsP $\mathrm{P}_{3}$ to examine this possibility. This depolarization induced a slow component in the rising phase of $\left[\mathrm{Ca}^{2+}\right]_{i}$, a marked prolongation of the overall duration of the $\mathrm{Ca}^{2+}$ transient, and a late component in the outward current (Fig. 4A). These effects of depolarization persisted for $>5 \min (n=3)$. When cells were dialyzed with ruthenium red $(20 \mu \mathrm{M})$, depolarization produced no significant change in the profile of the InsP ${ }_{3}$-elicited $\mathrm{Ca}^{2+}$ transient, and no late component was observed in the outward current $(n=3)$ (Fig. 4B). These results suggest that CICR through ryanodine receptors augments the $\mathrm{InsP}_{3}$-evoked $\mathrm{Ca}^{2+}$ release when intracellular stores are enlarged by prolonged depolarization. A transient reduction in the peak amplitude of the $\mathrm{InsP}_{3}$-induced current was also observed after the prolonged depolarization with both control and ruthenium red-containing internal solutions (Fig. $4 A, B$ ). The reason for this decrease in $\mathrm{InsP}_{3}$-induced current is not known.

\section{DISCUSSION}

The present study demonstrates that intracellularly released $\mathrm{InsP}_{3}$ induces activation of apamin-sensitive SK channels through mobilization of $\mathrm{Ca}^{2+}$ from intracellular stores in midbrain dopa- 
A Control

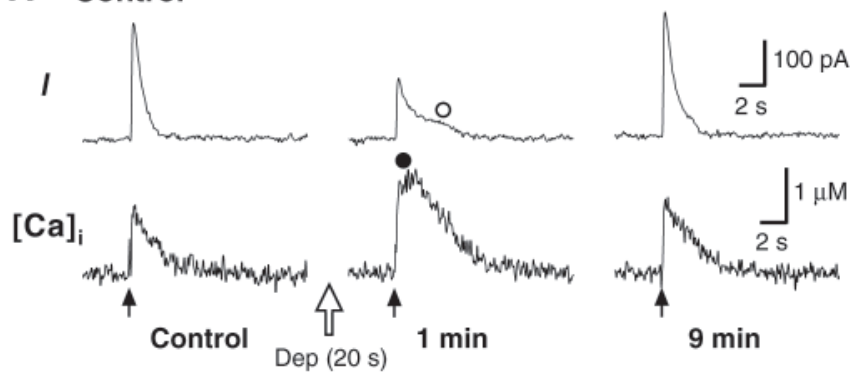

B Ruthenium red
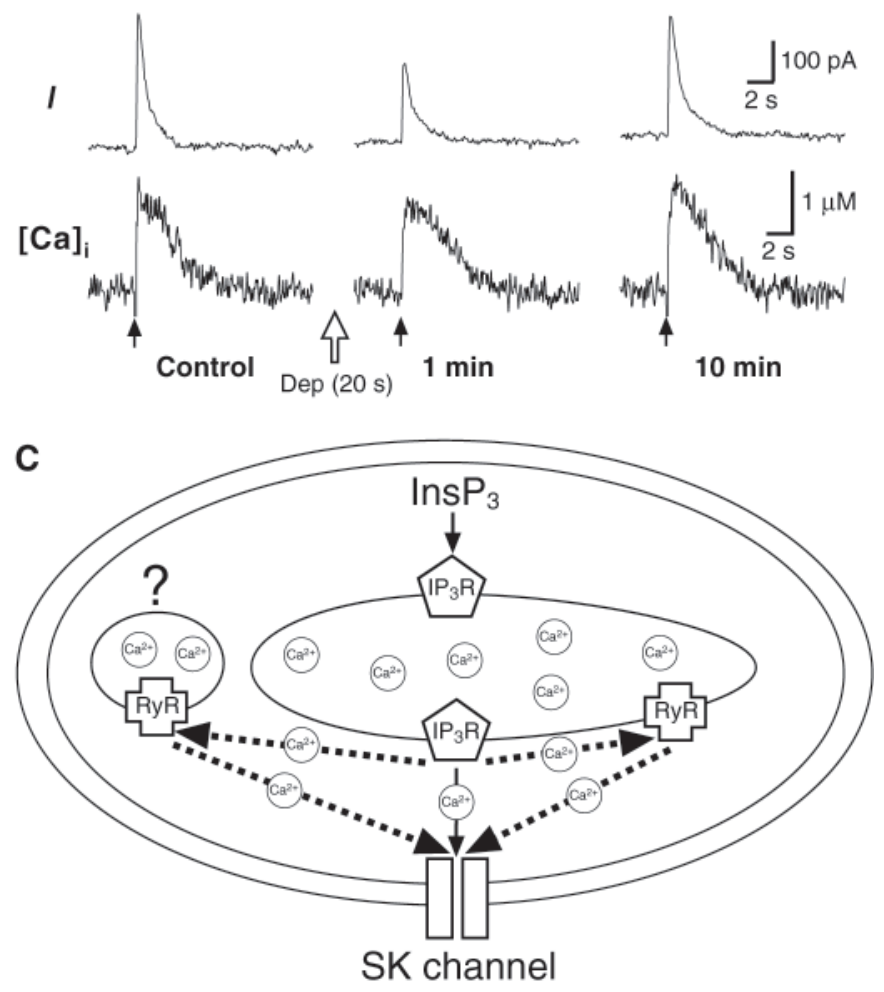

Figure 4. Prolonged depolarization added a CICR-mediated component to $\mathrm{InsP}_{3}$-induced responses. $A, \mathrm{InsP}_{3}(30 \mu \mathrm{M})$-evoked responses before (left traces) and after (middle and right traces) application of a prolonged depolarizing step to $0 \mathrm{mV}(20 \mathrm{sec}$; open arrow $)$, which caused a large increase in $\left[\mathrm{Ca}^{2+}\right]_{\mathrm{i}}(>2 \mu \mathrm{M})$. The interval between depolarization and release of $\mathrm{InsP}_{3}$, which is indicated below, was at least 1 min to allow the membrane current and $\left[\mathrm{Ca}^{2+}\right]_{\mathrm{i}}$ to recover to control levels after depolarization. The late component in the outward current and the slow component in the rising phase of $\left[\mathrm{Ca}^{2+}\right]_{\mathrm{i}}$ are marked with open and closed circles, respectively, which were observed when $\mathrm{InsP}_{3}$ was released 1 min after depolarization. $B$, Same experiment as in $A$ with ruthenium red $(20 \mu \mathrm{M})$ included in the pipette solution. $C$, Intracellular signaling cascade elicited by $\mathrm{InsP}_{3}$ in midbrain dopamine neurons. Solid arrows represent the pathway in control conditions, and dashed arrows represent the possible pathways invoked when intracellular $\mathrm{Ca}^{2+}$ stores are enlarged with prolonged depolarization. $I P_{3} R, \mathrm{Ins}_{3}$ receptor; $R y R$, ryanodine receptor.

mine neurons. It is shown that $\mathrm{InsP}_{3}$-sensitive stores are functionally connected to ryanodine-sensitive stores. Furthermore, evidence is provided suggesting that increasing $\mathrm{Ca}^{2+}$ stores facilitates $\mathrm{InsP}_{3}$-induced mobilization of $\mathrm{Ca}^{2+}$ by bringing ryanodine receptors into play.

The amplitude of the outward current was correlated with the peak $\left[\mathrm{Ca}^{2+}\right]_{i}$ after release of InsP $_{3}$. Thus, the increase in membrane conductance can be a reasonable measure of the increase in free cytosolic $\mathrm{Ca}^{2+}$ concentration. Furthermore, the relationship between the peak $\left[\mathrm{Ca}^{2+}\right]_{\mathrm{i}}$ and the current amplitude illustrated in
Figure $1 C$ is in good agreement with the known $\mathrm{EC}_{50}$ of $\mathrm{Ca}^{2+}$ for activation of cloned SK channels determined from inside-out patches (630-700 nM) (Köhler et al., 1996).

Depleting intracellular $\mathrm{Ca}^{2+}$ stores with CPA almost completely blocked the $\mathrm{InsP}_{3}$-evoked $\mathrm{Ca}^{2+}$ transient, even when the high-affinity $\mathrm{Ca}^{2+}$ indicator Fura-2 was used to enhance detection of a small change in $\left[\mathrm{Ca}^{2+}\right]_{\mathrm{i}}$. Furthermore, $\mathrm{InsP}_{3}$ elicited no change in the holding current after treatment with CPA, indicating that the outward current results entirely from mobilization of $\mathrm{Ca}^{2+}$ from intracellular stores. The time course of decay of $\left[\mathrm{Ca}^{2+}\right]_{\mathrm{i}}$ after $\mathrm{Ca}^{2+}$ influx attributable to membrane depolarization was slowed in the presence of CPA, possibly reflecting the blockade of $\mathrm{Ca}^{2+}$ sequestration into intracellular stores. Thus, $\mathrm{Ca}^{2+}$ entering the cell during depolarization can indeed be pumped into intracellular stores and charge them with $\mathrm{Ca}^{2+}$. It should be noted, however, that internal $\mathrm{Ca}^{2+}$ stores remained stable in dopamine cells clamped at $-60 \mathrm{mV}$, because release of $\mathrm{InsP}_{3}$ could elicit reproducible responses without membrane depolarization throughout the duration of the recording.

Ruthenium red, which blocks ryanodine receptors, failed to affect the $\mathrm{InsP}_{3}$-induced release of $\mathrm{Ca}^{2+}$ and the amplitude of mGluR IPSCs. Hence, ryanodine receptors do not appear to make a significant contribution to the $\mathrm{InsP}_{3}$-mediated responses. On the other hand, depletion of ryanodine-sensitive $\mathrm{Ca}^{2+}$ stores with ryanodine abolished $\mathrm{InsP}_{3}$-induced $\mathrm{Ca}^{2+}$ mobilization as well as the outward current. Ryanodine also blocked mGluR IPSPs (Fiorillo and Williams, 1998) and an outward current induced by iontophoresis of acetylcholine (Fiorillo and Williams, 2000) in dopamine neurons. Ruthenium red reversed the inhibitory effects of ryanodine on the $\mathrm{InsP}_{3}$-evoked responses (Fig. $3 \mathrm{~A}$ ) and the acetylcholine-induced outward current (Fiorillo and Williams, 2000), providing a positive control for the effectiveness of ruthenium red. These data, together with the lack of effect of ruthenium red on $\mathrm{InsP}_{3}$-induced $\mathrm{Ca}^{2+}$ mobilization, suggest that $\mathrm{InsP}_{3}$-sensitive stores also possess ryanodine receptors and can thus be depleted by ryanodine. Interestingly, the $\mathrm{InsP}_{3}$-evoked responses abolished by ryanodine partially recovered after depolarization of the cells. This observation is consistent with the idea that depolarization-induced $\mathrm{Ca}^{2+}$ influx refilled the $\mathrm{InsP}_{3}$ sensitive stores that had been depleted by ryanodine. This effect of depolarization could not be ascribed to CICR triggered by an increase in $\left[\mathrm{Ca}^{2+}\right]_{\mathrm{i}}$ after depolarization, because CICR is blocked in the presence of ryanodine. Furthermore, it is unlikely that this could be caused by $\mathrm{Ca}^{2+}$-induced activation of $\mathrm{InsP}_{3}$ receptors, because when $\mathrm{InsP}_{3}$ was released $5 \mathrm{sec}$ after the depolarizing step, $\left[\mathrm{Ca}^{2+}\right]_{\mathrm{i}}$ was still considerably high, i.e., $\sim 800 \mathrm{nM}$ (Fig. $3 B$ ), which is in a concentration range where $\mathrm{Ca}^{2+}$ inhibits $\mathrm{InsP}_{3}$ receptors (Bezprozvanny et al., 1991). It has also been reported that $\mathrm{InsP}_{3}$-sensitive stores are equipped with ryanodine receptors in cerebellar Purkinje neurons (Khodakhah and Armstrong, 1997) and hippocampal pyramidal neurons (Nakamura et al., 1999). However, the possibility remains that there are separate stores, in addition to these $\mathrm{InsP}_{3}$-sensitive stores equipped with ryanodine receptors, that are regulated exclusively by ryanodine receptors.

Increasing the size of intracellular $\mathrm{Ca}^{2+}$ stores with prolonged depolarization potentiated $\mathrm{InsP}_{3}$-evoked responses by inducing CICR through ryanodine receptors. Regenerative release of $\mathrm{Ca}^{2+}$ via ryanodine receptors produced a slow component in the rising phase of $\left[\mathrm{Ca}^{2+}\right]_{i}$ and an overall prolongation of the duration of $\mathrm{Ca}^{2+}$ transient, which was reflected in a late component of the outward current. It should be noted that increasing the size of internal stores with prolonged depolarization did not cause an increase in the magnitude of $\left[\mathrm{Ca}^{2+}\right]_{\mathrm{i}}$ elevation when ryanodine receptors were blocked with ruthenium red. It is possible that filling the $\mathrm{InsP}_{3}$-sensitive stores did not result in an elevated peak $\left[\mathrm{Ca}^{2+}\right]_{\mathrm{i}}$ attained by $\mathrm{Ca}^{2+}$ mobilization through $\mathrm{InsP}_{3}$ receptors themselves, because enhanced initial release of $\mathrm{Ca}^{2+}$ can in turn 
cause $\mathrm{Ca}^{2+}$-induced inactivation of $\mathrm{InsP}_{3}$ receptors to terminate $\mathrm{InsP}_{3}$ receptor-mediated $\mathrm{Ca}^{2+}$ release (Ogden and Capiod, 1997). Alternatively, $\mathrm{Ca}^{2+}$ entering the cell during depolarization may have preferentially filled separate ryanodine-sensitive stores that are devoid of $\mathrm{InsP}_{3}$ receptors.

The schematic illustration depicted in Figure $4 C$ summarizes how generation of $\mathrm{InsP}_{3}$ inside the cell leads to activation of SK channels on the plasma membrane in midbrain dopamine neurons. Intracellular InsP $\mathrm{P}_{3}$ activates $\mathrm{InsP}_{3}$ receptors on the internal stores that also contain ryanodine receptors. Under control conditions in which the membrane potential is clamped at $-60 \mathrm{mV}$, $\mathrm{InsP}_{3}$ receptor-mediated release of $\mathrm{Ca}^{2+}$ leads to activation of SK channels with no significant contribution from ryanodine receptors. When intracellular stores are enlarged by depolarization-induced $\mathrm{Ca}^{2+}$ influx, $\mathrm{Ca}^{2+}$ released from the $\mathrm{InsP}_{3}$-sensitive stores can now elicit ryanodine receptor-mediated release of $\mathrm{Ca}^{2+}$, i.e., CICR, from the same stores and/or from separate stores that possess only ryanodine receptors. This will result in an augmentation of $\mathrm{Ca}^{2+}$ mobilization and a prolongation of SK channel activation. Dopamine neurons are spontaneously active and fire continuously both in vivo and in vitro (Sanghera et al., 1984). It is therefore possible that this spontaneous firing keeps internal $\mathrm{Ca}^{2+}$ stores filled and thus enables $\mathrm{InsP}_{3}$ to induce CICR under physiological conditions.

SK channels are known to participate in controlling the firing pattern of midbrain dopamine neurons (Shepard and Bunney, 1991). Thus, it is very likely that mobilization of $\mathrm{Ca}^{2+}$ from intracellular stores plays an important role in regulating the activity of dopamine neurons. Activation of dopamine neurons is critically involved in the reinforcing actions of drugs of abuse, such as opioids and psychostimulants (Koob et al., 1998). Future investigation on how these drugs interact with the intracellular signaling pathway described here may lead to a better understanding of the cellular mechanisms underlying drug addiction.

\section{REFERENCES}

Bezprozvanny I, Watras J, Ehrlich BE (1991) Bell-shaped calciumresponse curves of Ins $(1,4,5) \mathrm{P}_{3}$ - and calcium-gated channels from endoplasmic reticulum of cerebellum. Nature 351:751-754.

Cameron DL, Williams JT (1994) Cocaine inhibits GABA release in the VTA through endogenous 5-HT. J Neurosci 14:6763-6767.

Denk W, Yuste R, Svoboda K, Tank DW (1996) Imaging calcium dynamics in dendritic spines. Curr Opin Neurobiol 6:372-378.

Finch EA, Augustine GJ (1998) Local calcium signalling by inositol1,4,5-trisphosphate in Purkinje cell dendrites. Nature 396:753-756.

Fiorillo CD, Williams JT (1998) Glutamate mediates an inhibitory postsynaptic potential in dopamine neurons. Nature 394:78-82.
Fiorillo CD, Williams JT (2000) Cholinergic inhibition of ventral midbrain neurons. J Neurosci, in press.

Johnson SW, North RA (1992) Two types of neurone in the rat ventral tegmental area and their synaptic inputs. J Physiol (Lond) 450:455-468.

Khodakhah K, Armstrong CM (1997) Inositol trisphosphate and ryanodine receptors share a common functional $\mathrm{Ca}^{2+}$ pool in cerebellar Purkinje neurons. Biophys J 73:3349-3357.

Köhler M, Hirschberg B, Bond CT, Kinzie JM, Marrion NV, Maylie J, Adelman JP (1996) Small-conductance, calcium-activated potassium channels from mammalian brain. Science 273:1709-1714.

Koob GF, Sanna PP, Bloom FE (1998) Neuroscience of addiction. Neuron 21:467-476.

Nakamura T, Barbara JG, Nakamura K, Ross WN (1999) Synergistic release of $\mathrm{Ca}^{2+}$ from $\mathrm{IP}_{3}$-sensitive stores evoked by synaptic activation of mGluRs paired with backpropagating action potentials. Neuron 24:727-737.

Ogden D, Capiod T (1997) Regulation of $\mathrm{Ca}^{2+}$ release by $\mathrm{InsP}_{3}$ in single guinea pig hepatocytes and rat Purkinje neurons. J Gen Physiol 109:741-756.

Ogden D, Khodakhah K, Carter T, Thomas M, Capiod T (1995) Analogue computation of transient changes of intracellular free $\mathrm{Ca}^{2+}$ concentration with the low affinity $\mathrm{Ca}^{2+}$ indicator furaptra during whole-cell patch-clamp recording. Pflügers Arch 429:587-591.

Sanghera MK, Trulson ME, German DC (1984) Electrophysiological properties of mouse dopamine neurons: in vivo and in vitro studies. Neuroscience 12:793-801.

Schultz W (1998) Predictive reward signal of dopamine neurons. J Neurophysiol 80:1-27.

Seidler NW, Jona I, Vegh M, Martonosi A (1989) Cyclopiazonic acid is a specific inhibitor of the $\mathrm{Ca}^{2+}$-ATPase of sarcoplasmic reticulum. J Biol Chem 264:17816-17823.

Seutin V, Mkahli F, Massotte L, Dresse A (2000) Calcium release from internal stores is required for the generation of spontaneous hyperpolarizations in dopaminergic neurons of neonatal rats. J Neurophysiol 83:192-197.

Shepard PD, Bunney BS (1991) Repetitive firing properties of putative dopamine-containing neurons in vitro: regulation by an apaminsensitive $\mathrm{Ca}^{2+}$-activated $\mathrm{K}^{+}$conductance. Exp Brain Res 86:141-150.

Smith JS, Imagawa T, Ma J, Fill M, Campbell KP, Coronado R (1988) Purified ryanodine receptor from rabbit skeletal muscle is the calciumrelease channel of sarcoplasmic reticulum. J Gen Physiol 92:1-26.

Takechi H, Eilers J, Konnerth A (1998) A new class of synaptic response involving calcium release in dendritic spines. Nature 396:757-760.

Vergara C, Latorre R, Marrion NV, Adelman JP (1998) Calciumactivated potassium channels. Curr Opin Neurobiol 8:321-329.

Walker JW, Reid GP, McCray JA, Trentham DR (1988) Photolabile 1-(2-nitrophenyl)ethyl phosphate esters of adenine nucleotide analogues. Synthesis and mechanism of photolysis. J Am Chem Soc 110:7170-7177.

Walker JW, Feeney J, Trentham DR (1989) Photolabile precursors of inositol phosphates. Preparation and properties of 1-(2nitrophenyl)ethyl esters of myo-inositol 1,4,5-trisphosphate. Biochemistry 28:3272-3280.

Womack MD, Walker JW, Khodakhah K (2000) Impaired calcium release in cerebellar Purkinje neurons maintained in culture. J Gen Physiol 115:339-346. 